\title{
Profile of vismodegib and its potential in the treatment of advanced basal cell carcinoma
}

\author{
This article was published in the following Dove Press journal: \\ Cancer Management and Research \\ 30 July 2013 \\ Number of times this article has been viewed
}

\author{
Muzafar A Macha' \\ Surinder K Batra ${ }^{1,2}$ \\ Apar Kishor Ganti3,4 \\ 'Department of Biochemistry and \\ Molecular Biology, University of \\ Nebraska Medical Center, Omaha, \\ ${ }^{2}$ Eppley Institute for Research in \\ Cancer and Allied Diseases, University \\ of Nebraska Medical Center, Omaha, \\ ${ }^{3}$ Department of Internal Medicine, \\ VA Nebraska-Western lowa Health \\ Care System, Omaha, ${ }^{4}$ Division of \\ Oncology-Hematology, Department \\ of Internal Medicine, University \\ of Nebraska Medical Center, Omaha, \\ NE, USA
}

\begin{abstract}
Basal cell carcinoma (BCC) is the most common human malignancy. Recent advances in our understanding of the critical biologic pathways implicated in the development and progression of BCC have led to the development of the first molecular targeted therapy for this disease. The hedgehog pathway is mutated in virtually all patients with BCC and recent trials with vismodegib, an inhibitor of this pathway, have shown significant responses. This review will discuss the importance of the hedgehog pathway in the pathogenesis of $\mathrm{BCC}$ and describe in detail the pharmacology of vismodegib in relation to its activity in advanced BCC.
\end{abstract}

Keywords: basal cell carcinoma, vismodegib, hedgehog pathway

\section{Introduction}

Basal cell carcinoma (BCC) is the most common human malignancy. Since it is not always included in cancer registries, the true incidence is unknown. It is estimated that approximately 3.5 million nonmelanoma skin cancers in 2.2 million patients are treated annually in the United States, the majority of which are BCC (American Cancer Society, Facts and Figures 2013). The American Academy of Dermatology estimates that approximately 2 million BCC are treated every year (http://www.aad.org/dermatology-a-to-z/diseasesand-treatments/a---d/basal-cell-carcinoma). Fortunately, these tumors are usually amenable to local therapy and only $1 \%-5.3 \%$ of lesions recur after initial resection. ${ }^{1}$

Interestingly, even locally aggressive tumors seldom metastasize and metastatic $\mathrm{BCC}$ is quite rare. Since accurate incidence records of this disease are not available, the burden of metastatic disease is difficult to ascertain. Rates ranging from $0.0028 \%$ to $0.55 \%$ of patients with BCC developing metastases have been reported, ${ }^{2-7}$ but even these have been questioned. ${ }^{8}$ The median age of patients with metastatic BCC at the time of diagnosis of the primary lesion is about 45-56 years, and metastases appear at a median of about 9 years later. ${ }^{9-11}$ Factors that may predispose to the development of metastatic BCC include male gender, ${ }^{9}$ primary lesion in the ear region ${ }^{9,11,12}$ and face, ${ }^{11}$ large ${ }^{11}$ and locally invasive ${ }^{13}$ primary tumors, recurrence following initial treatment, ${ }^{11}$ and impairment of cell mediated immunity (eg, acquired immunodeficiency syndrome, therapeutic immunosuppression). ${ }^{14,15}$

Recent advances in our understanding of the biologic pathways that appear to be important in the development and progression of BCC have led to the development of the first molecular targeted therapy for this disease, vismodegib. The hedgehog $(\mathrm{Hh})$ pathway is mutated in virtually all patients with BCC and inhibition of this pathway with vismodegib appears to result in significant clinical responses. The following 
sections will discuss the importance of the Hh pathway in the pathogenesis of BCC and describe in detail the pharmacology of vismodegib in relation to advanced BCC.

\section{Hh pathway and its role in BCC}

The Hh pathway is one of the most common signal transduction pathways used by mammalian cells ${ }^{16}$ for normal embryonic development of the neural tube, axial skeleton, skin, and hair, ${ }^{17}$ and for wound healing during postnatal life. ${ }^{18}$ While this pathway appears to be silenced in most adult tissues, ${ }^{19}$ it has been shown to promote the proliferation of stem cells from various tissues in the adult. These include hematopoietic cells, ${ }^{20}$ mammary, ${ }^{21}$ mesenchymal, ${ }^{22}$ and neura ${ }^{23}$ stem cells. This pathway also appears to play a role in the transition of hair follicles from the resting to the growth phase. ${ }^{24}$ This could explain the alopecia noted in patients treated with the Hh pathway inhibitor, vismodegib. In addition, this pathway seems to be involved in the repair of various organs in the adult following injury. ${ }^{25-27}$
Recent studies have shown that aberrant Hh signaling pathway is involved in the pathogenesis, self-renewal of stem cells, and chemotherapeutic resistance of BCC..$^{28,29}$ Besides $\mathrm{BCC}$, Hh signaling is also activated in other malignancies such as medulloblastoma, ${ }^{30,31}$ colon, ${ }^{32}$ prostate, ${ }^{33,34}$ breast, ${ }^{35}$ lung, ${ }^{36}$ and various hematologic malignancies. ${ }^{37-40}$ The $\mathrm{Hh}$ pathway dependent gene upregulation leads to increased cell proliferation and cell survival, and promotes bone metastases. ${ }^{41}$ This pathway has been shown to regulate the epithelial-mesenchymal transition and dissemination of cancer stem cells in solid tumors, ${ }^{42,43}$ and enhance metastatic disease progression. ${ }^{44}$ These observations suggest that targeted inhibition of Hh signaling may be an effective treatment strategy for several human cancers.

The signaling cascade of the Hh pathway in mammalian cells is initiated by binding of one of three Hh ligands (sonic, Indian, or desert $\mathrm{Hh}$ ) to the 12 pass transmembrane receptor patched 1 (Ptch1) (Figure 1). This causes internalization and degradation of Ptch1, thereby releasing smoothened (SMO),

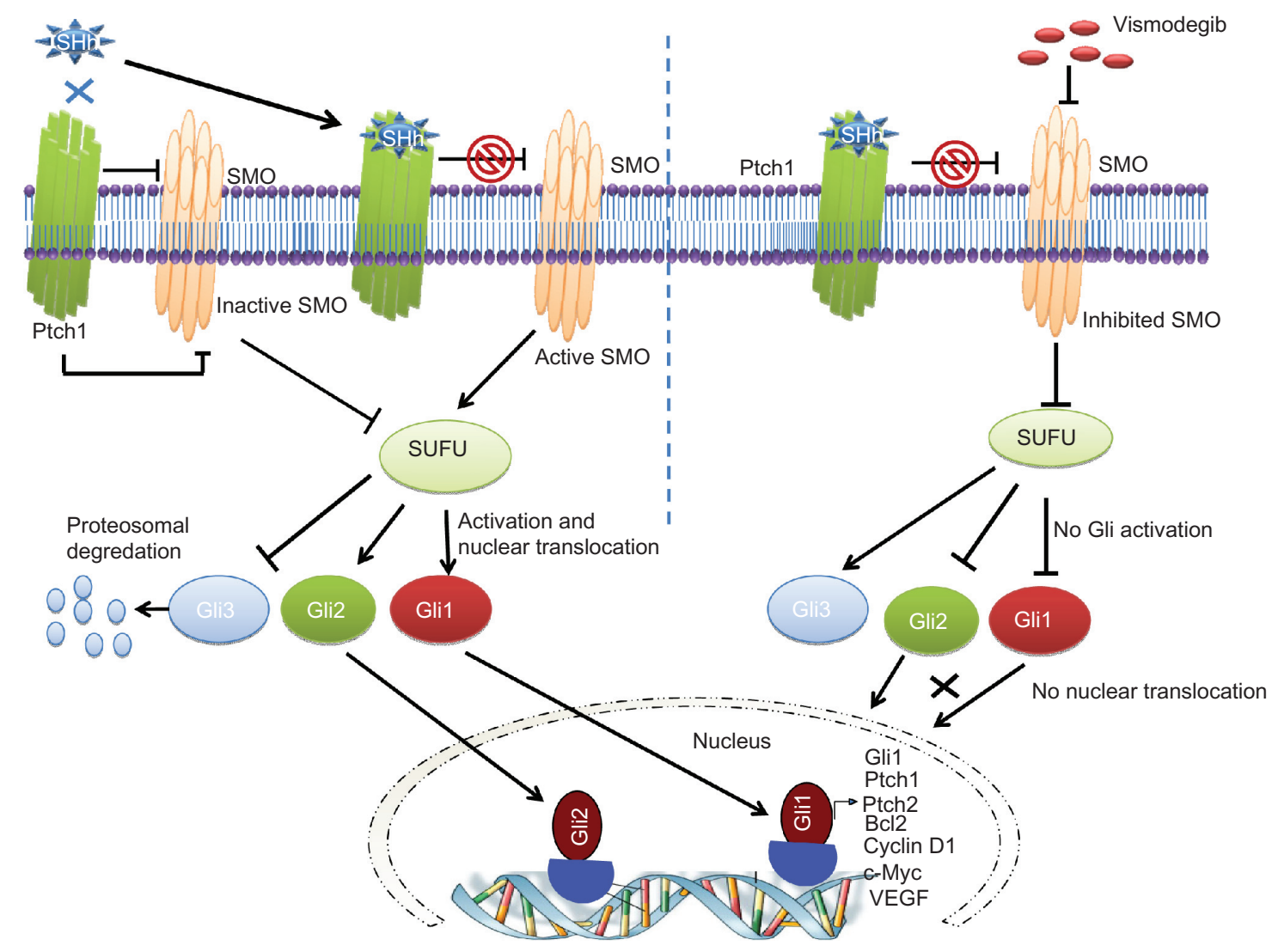

Figure I A schematic diagram showing inhibition of Hedgehog $(\mathrm{Hh})$ signaling by vismodegib.

Notes: The extracellular Hh ligands (Sonic, Indian, or Desert Hh) bind to Patched I (Ptchl), relieving the inhibition of Smoothened (SMO) by Ptch I. SMO disrupts the cytoplasmic complex containing the Suppressor of Fused (SUFU)-glioma-associated oncogene homologue (Gli) complex resulting in degradation of Gli3 and translocation of Glil and Gli2 to the nucleus to upregulate target genes like PtchI, Glil, c-Myc, Bcl2, vascular endothelial growth factor, and cyclin DI. Vismodegib binds to the extracellular domain of SMO, markedly inhibiting the release and translocation of Glil and Gli2 to the nucleus.

Abbreviations: Gli, glioma-associated oncogene homologue; Ptch I, patched I; SHh, sonic hedgehog; SMO, smoothened; SUFU, Suppressor of Fused; VEGF, vascular endothelial growth factor. 
a 7 pass transmembrane $G$ protein coupled receptor like protein. This protein then enters the primary cilia and disrupts the cytoplasmic complex containing Suppressor of Fused (SUFU)-glioma-associated oncogene homologue (Gli). The SUFU regulates transcriptional factors (Glis) through posttranslational modifications like phosphorylation, sumoylation, and selective proteolysis. ${ }^{45}$ Release of Gli transcription factors (Gli 1-3) from SUFU inhibition results in nuclear translocation and upregulation of Gli1 associated target genes that include Gli1, Ptch1, cyclin D1, c-Myc, vascular endothelial growth factor, Bcl2 , and snail, depending upon cell type ${ }^{46}$ and degradation of the repressor transcription factor Gli3. Depending on the Gli2 posttranscriptional and posttranslational processing events, Gli2 has been shown to act as either a positive or negative regulator of Hh pathway signaling. ${ }^{47}$ Deregulated Hh signaling has been associated with either mutations in pathway genes or overexpression of signaling molecules in either tumor cells themselves or in cells within the supportive tumor microenvironment. ${ }^{46,48-51}$

The first link between the Hh pathway and BCC came from the discovery of loss-of-function mutations of Ptch1 gene in Gorlin syndrome. ${ }^{29,52}$ Patients with Gorlin syndrome are strongly predisposed to the development of $\mathrm{BCC}$ at an early age. Recent molecular and genetic studies have shown that almost all BCC tumors contain genetic alterations in components of the Hh signaling pathway and these tumors have elevated Ptch and Glil messenger (m)RNA levels. ${ }^{53,54}$ This ligand-independent mechanism of $\mathrm{Hh}$ activation, driven by specific Hh gene mutations within the tumor cells, is termed Type I Hh signaling. ${ }^{46}$ It has been estimated that almost $90 \%$ of sporadic BCCs have loss-of-function mutation in at least one allele of Ptch1 and in addition, around 10\% have activating mutations in the SMO, rendering it resistant to Ptch1 inhibition. ${ }^{28,55-57}$ In contrast, mutations in other downstream molecules of the Hh pathway appear to be rare in BCC. In a study of 42 patients with sporadic BCC, only two patients had mutations in $S U F U$, one of which was a missense mutation and the other a silent mutation. ${ }^{58}$ No mutation was seen in Gli1.

\section{Pharmacology of vismodegib Structure}

Vismodegib is an orally active SMO inhibitor (2-chloro$N$-[4-chloro-3-pyridin-2-yl-phenyl]-4-methanesulfonyl benzamide) with a molecular weight $421.30 \mathrm{~g} / \mathrm{mol}$ (Figure 2).

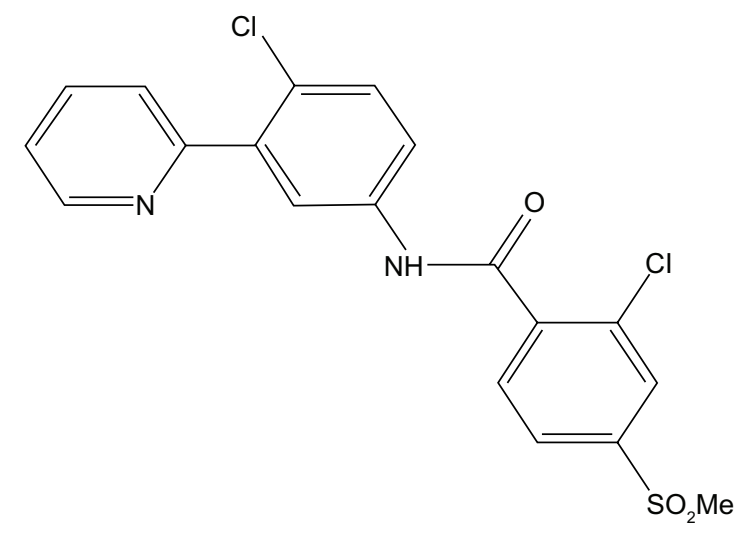

Figure 2 Chemical structure of vismodegib.

Note: Structure of vismodegib is courtesy of Genentech.

\section{Preclinical evidence}

Vismodegib was shown to be effective in suppressing Gli in the Hh responsive tumor cell line CALU-6 when implanted in nude mice. ${ }^{59}$ It was also effective in producing complete regression of the Hh pathway dependent medulloblastoma allograft model generated from $\mathrm{Ptch}^{+/-}$mice. ${ }^{59}$

\section{Pharmacokinetics}

Vismodegib has an unusual pharmacokinetic profile. It demonstrates saturable absorption with a dose dependent increase in absorption until a dose of $540 \mathrm{mg}$, beyond which the degree of absorption does not appear to increase. ${ }^{60}$ This could explain the plateau of the rise in concentration of the drug within the first 14 days. The drug reaches its steady state concentration in the plasma in about 7-14 days after initiation of therapy. Vismodegib is highly protein bound to albumin and $\alpha_{1}$-acid glycoprotein. Plasma concentrations of total vismodegib appear to be strongly correlated with $\alpha_{1}$-acid glycoprotein levels. ${ }^{60,61}$ Food does not seem to affect the degree of absorption of vismodegib.

Vismodegib undergoes oxidation mediated by the cytochrome P450 (CYP) enzymes CYP2C9, CYP3A4, and CYP3A5, and the oxidative metabolites are excreted in the feces. ${ }^{62,63}$ In addition, vismodegib undergoes glucuronidation and pyridine ring cleavage to a smaller extent. ${ }^{62}$ A study in dogs and rats found that a small proportion of the drug was metabolized by an uncommon pyridine ring opening. ${ }^{64}$ These metabolites were excreted in the feces as well. In pharmacokinetic studies, vismodegib had an elimination half-life of approximately 12 days after a single dose. However this duration decreased to 4 days after repeated, once-daily administration, suggesting an increased clearance with repeated administration. ${ }^{65}$ 
Although it has not been specifically studied, based on the pharmacokinetic profile, it is unlikely that renal dysfunction affects the safety profile of vismodegib significantly. Hence, patients with renal dysfunction are not likely to need a modification of their dose. The need for dose modification in patients with hepatic dysfunction is currently unknown.

\section{Pharmacodynamics}

Vismodegib binds to, and inactivates, SMO. This prevents its translocation when Ptch1 is stimulated by Hh ligands and leads to the inhibition of the downstream signaling pathways and a decrease in the production of downstream proliferation factors (Figure 1). ${ }^{66}$

Exposure to vismodegib leads to the downregulation of Gli1. In a Phase I trial of vismodegib in patients with locally advanced or metastatic solid tumors there was $>2$ fold downmodulation of Glil expression in skin biopsies from almost $75 \%$ patients, compared with pretreatment specimens. ${ }^{66}$ In the same study, a similar proportion of patients with BCC showed $>2$ fold downmodulation of Glil expression. However, the downmodulation of Gli1 expression was not associated with plasma concentrations of the drug.

\section{Adverse effects}

Vismodegib is relatively well tolerated. The most common adverse reactions seen in clinical trials have been muscle spasms $(70 \%)$, alopecia $(60 \%)$, dysgeusia $(55 \%)$, weight loss $(45 \%)$, fatigue $(40 \%)$, nausea $(30 \%)$, diarrhea $(30 \%)$, decreased appetite (25\%), constipation (20\%), arthralgias (15\%), vomiting (12\%), and ageusia (10\%). ${ }^{67}$ Approximately 30\% of premenopausal women developed amenorrhea while on vismodegib. Other laboratory abnormalities noted by patients on clinical trials included hyponatremia (4\%), hypokalemia (1\%), and azotemia (2\%). A recent report described the development of keratoacanthomas in two patients, who did not have a history of previous squamous cell carcinomas, while being treated with vismodegib ${ }^{68}$ While the authors were not able to establish a causal relationship with vismodegib, clinicians need to be alert to these findings.

The vismodegib package insert contains a black box warning regarding the risk of severe birth defects and embryonic fetal death. This is based on rat studies, which demonstrated that vismodegib administered at a dose of $10 \mathrm{mg} / \mathrm{kg} /$ day showed teratogenic effects. ${ }^{69}$ This dose corresponds to an exposure of approximately $20 \%$ of the human exposure at the recommended dose of $150 \mathrm{mg}$ daily. Similarly, there is a potential risk of exposure to the drug through semen. Hence, sexually active individuals receiving vismodegib should be advised of the need for contraception (Source: Erivedge ${ }^{\mathrm{TM}}$ package insert. http:// www.gene.com/download/pdf/erivedge prescribing.pdf).

\section{Drug resistance}

Resistance mechanisms to vismodegib have not been extensively studied, which is understandable given the relatively short clinical experience with this drug. However, anecdotal reports of acquired resistance to vismodegib are beginning to emerge. In the only case reported thus far, a 26 year old man with treatment refractory metastatic medulloblastoma who was treated with vismodegib responded initially, but developed progressive disease after 3 months, suggesting the development of resistance. A molecular analysis of the biopsy specimen obtained at disease progression showed a heterozygous $\mathrm{G}$ to $\mathrm{C}$ missense mutation at position 1697, which is responsible for a change in codon 473 from aspartic acid to histidine (D473H).$^{70}$ This mutation prevents the binding of vismodegib to SMO, thereby leading to resistance.

This was further studied in vitro by Dijkgraaf et al who replaced the aspartic acid at position 473 of the SMO gene with every other amino acid and found that vismodegib did not bind to SMO in any of the mutant variations, thereby suggesting that D473 is critical for SMO binding by vismodegib. ${ }^{71}$ It is unclear, however, if D473 is directly involved in the binding of vismodegib or if its main role is to maintain the necessary SMO conformation for binding.

Other potential resistance mechanisms identified in vitro include mutations at E518. ${ }^{71}$ Substitution of glutamic acid at this site conferred complete resistance to vismodegib. Other possible mechanisms of resistance include focal amplifications of the transcription factor Gli2 and the target gene $C$ cnd 1 , which exert their actions downstream of SMO. ${ }^{11}$ There are initial data on resistance to vismodegib in BCC, which are described below.

Mechanisms to overcome this resistance are currently being studied. Dijkgraaf et $\mathrm{al}^{71}$ screened multiple chemically diverse Hh pathway inhibitors and were able to identify several compounds that were active against the two known SMO resistance mutations, SMO-D473H and SMO-E518K. Available data also suggest that Hh pathway resistant medulloblastoma allografts may respond to inhibition of phosphoinositide-3-kinase. ${ }^{71}$

\section{Clinical data on vismodegib}

The Phase I trial of vismodegib included 68 patients with different malignancies, of which 33 had advanced BCC. ${ }^{66}$ 
Vismodegib was well tolerated with only six patients (8.8\%) developing grade 4 adverse events (hyponatremia, fatigue, pyelonephritis, presyncope, resectable pancreatic adenocarcinoma, and paranoia with hyperglycemia). A maximum tolerated dose was not reached and based on achievement of maximal plasma concentration and response, the recommended Phase II dose was $150 \mathrm{mg}$ daily. Interestingly, 20 patients (19 with BCC and one with medulloblastoma) had a response based on Response Evaluation Criteria in Solid Tumors (RECIST) criteria. ${ }^{72}$ At the time of publication, the median duration of response in patients with advanced BCC was 12.8 months (range 3.7-26.4 months). This led to further investigation of vismodegib in BCC.

A multicenter, international, two cohort, nonrandomized Phase II study, administered $150 \mathrm{mg}$ of oral vismodegib daily to patients with either metastatic or locally advanced BCC (inoperable disease or for whom surgery was inappropriate, ie, multiple recurrences and a low likelihood of cure, or substantial anticipated disfigurement). ${ }^{73}$ The response rate was $30 \%$ for patients with metastatic BCC and $43 \%$ ( $21 \%$ complete response) in patients with locally advanced BCC. The median duration of response was 7.6 months in both cohorts. The most common adverse events were muscle spasms, alopecia, dysgeusia, weight loss, and fatigue. Serious adverse events were reported in $25 \%$ of patients. Seven deaths were reported, although their relationship to the study drug was unclear. The results of these studies led to the approval of vismodegib for the treatment of metastatic BCC and locally advanced $\mathrm{BCC}$ in patients who are not candidates for surgery or radiation based on the location or size of the lesion.

More recently, vismodegib has been studied for its potential to prevent the development of BCC in patients with basal cell nevus syndrome. In a randomized placebo controlled trial, 42 patients with the basal cell nevus syndrome were randomly assigned to either vismodegib (150 mg daily) or placebo for 18 months. ${ }^{74}$ The primary end point of this study was the rate of development of new BCC that were eligible for surgical resection. Vismodegib significantly reduced the rate of new surgically eligible basal cell carcinomas when compared to placebo ( 2 versus 29 new surgically eligible BCC per group annually; $P<0.001)$. Vismodegib also reduced the size of existing BCC (median decrease $71 \%$ ) when compared to placebo (median decrease $21 \% ; P=0.003)$. Patients receiving vismodegib had fewer surgeries for BCC (mean of -0.31 ), compared with those receiving placebo (mean $-4.4 ; P<0.001$ ). Palmar and plantar pits, pathognomonic signs of the basal cell nevus syndrome, also disappeared with vismodegib. However, almost half of the patients had to discontinue treatment due to drug related adverse events.

Recently, an interesting phenomenon of tumor regrowth was reported in patients treated with vismodegib. ${ }^{75}$ In a retrospective analysis of 28 patients on vismodegib, Chang et al noted tumor regrowth within or adjacent to $(\leq 1 \mathrm{~cm})$ the prior tumor bed in $6(21 \%)$ patients. $^{75}$ Surprisingly, none of the eight patients with metastatic $\mathrm{BCC}$ in their analysis demonstrated regrowth after initial shrinkage. Hence, close clinical examination of patients, even examination of those who have a response to therapy, is warranted to detect the development of secondary resistance to vismodegib. These findings would also suggest that vismodegib and other agents targeting the Hh pathway are unlikely to cure BCC, and surgery still would be considered the best curative option for patients who can undergo the procedure without major cosmetic deformity.

\section{Conclusion}

The Hh pathway is critical to the development of BCC. Mutations in this pathway are seen in virtually all patients with BCC. Inhibition of this pathway with the SMO inhibitor, vismodegib, leads to significant responses in patients with metastatic and locally advanced BCC. While vismodegib can delay the development of BCC in patients with the basal cell nevus syndrome, its adverse effect profile tempers its use in this setting. Finally, there are reports of resistance to vismodegib and those mechanisms are currently being studied.

\section{Acknowledgments}

The authors on this manuscript, in part, were supported by the VA Career Development Award (AKG) and NIH grants (UO1 EDRN CA 111294, P50 SPORE CA127297, and U54 TMEN CA160163) (SKB).

\section{Disclosure}

The authors report no conflicts of interest in this work.

\section{References}

1. Thissen MR, Neumann MH, Schouten LJ. A systematic review of treatment modalities for primary basal cell carcinomas. Arch Dermatol. 1999; 135:1177-1183

2. Paver K, Poyzer K, Burry N, Deakin M. Letter: The incidence of basal cell carcinoma and their metastases in Australia and New Zealand. Australas J Dermatol. 1973;14:53.

3. Cade S. Malignant Disease and its Treatment by Radium. Baltimore: Williams and Wilkins Company; 1940.

4. Cotran RS. Metastasizing basal cell carcinomas. Cancer. 1961;14: 1036-1040.

5. Lakshmipathi T, Hunt KM. Metastasizing basal-cell carcinoma. $\mathrm{Br} J$ Dermatol. 1967;79:267-270. 
6. Scanlon EF, Volkmer DD, Oviedo MA, Khanedar JD, Victor TA. Metastatic basal cell carcinoma. J Surg Oncol. 1980;15:171-180.

7. Wronkowski Z. Przerzuty raka podstawnokomorkowego skory [Metastases in dermal basal cell carcinoma.] Nowotwory. 1968;18:51-55. Polish.

8. Wadhera A, Fazio M, Bricca G, Stanton O. Metastatic basal cell carcinoma: a case report and literature review. How accurate is our incidence data? Dermatol Online J. 2006;12:7.

9. von Domarus H, Stevens PJ. Metastatic basal cell carcinoma. Report of five cases and review of 170 cases in the literature. JAm Acad Dermatol. 1984;10:1043-1060.

10. Weiss GJ, Korn RL. Metastatic basal cell carcinoma in the era of hedgehog signaling pathway inhibitors. Cancer. 2012;118:5310-5319.

11. Snow SN, Sahl W, Lo JS, et al. Metastatic basal cell carcinoma. Report of five cases. Cancer. 1994;73:328-335.

12. Lo JS, Snow SN, Reizner GT, Mohs FE, Larson PO, Hruza GJ. Metastatic basal cell carcinoma: report of twelve cases with a review of the literature. J Am Acad Dermatol. 1991;24:715-719.

13. Berlin JM, Warner MR, Bailin PL. Metastatic basal cell carcinoma presenting as unilateral axillary lymphadenopathy: report of a case and review of the literature. Dermatol Surg. 2002;28:1082-1084.

14. Sitz KV, Keppen M, Johnson DF. Metastatic basal cell carcinoma in acquired immunodeficiency syndrome-related complex. JAMA. 1987;257:340-343.

15. Walling HW, Fosko SW, Geraminejad PA, Whitaker DC, Arpey CJ. Aggressive basal cell carcinoma: presentation, pathogenesis, and management. Cancer Metastasis Rev. 2004;23:389-402.

16. Merchant JL. Hedgehog signalling in gut development, physiology and cancer. $J$ Physiol. 2012;590:421-432.

17. Tang JY, So PL, Epstein EH Jr. Novel Hedgehog pathway targets against basal cell carcinoma. Toxicol Appl Pharmacol. 2007;224:257-264.

18. Barakat MT, Humke EW, Scott MP. Learning from Jekyll to control Hyde: Hedgehog signaling in development and cancer. Trends Mol Med. 2010;16:337-348.

19. Ingham PW, McMahon AP. Hedgehog signaling in animal development: paradigms and principles. Genes Dev. 2001;15: 3059-3087.

20. Bhardwaj G, Murdoch B, Wu D, et al. Sonic hedgehog induces the proliferation of primitive human hematopoietic cells via BMP regulation. Nat Immunol. 2001;2:172-180.

21. Liu S, Dontu G, Mantle ID, et al. Hedgehog signaling and Bmi-1 regulate self-renewal of normal and malignant human mammary stem cells. Cancer Res. 2006;66:6063-6071.

22. James AW, Pang S, Askarinam A, et al. Additive effects of sonic hedgehog and Nell-1 signaling in osteogenic versus adipogenic differentiation of human adipose-derived stromal cells. Stem Cells Dev. 2012;21:2170-2178.

23. Ahn S, Joyner AL. In vivo analysis of quiescent adult neural stem cells responding to Sonic hedgehog. Nature. 2005;437:894-897.

24. Paladini RD, Saleh J, Qian C, Xu GX, Rubin LL. Modulation of hair growth with small molecule agonists of the hedgehog signaling pathway. J Invest Dermatol. 2005;125:638-646.

25. Michelotti GA, Xie G, Swiderska M, et al. Smoothened is a master regulator of adult liver repair. J Clin Invest. Epub April 8, 2013.

26. Zarogoulidis P, Zarampouka K, Huang H, et al. Hedgehog signaling pathway: the must, the maybe and the unknown. J Thorac Dis. 2013;5: 195-197.

27. Wang S, Hyun J, Youn B, Jung Y. Hedgehog signaling regulates the repair response in mouse liver damaged by irradiation. Radiat Res. 2013;179:69-75.

28. Gailani MR, Stahle-Backdahl M, Leffell DJ, et al. The role of the human homologue of Drosophila patched in sporadic basal cell carcinomas. Nat Genet. 1996;14:78-81.

29. Hahn H, Christiansen J, Wicking C, et al. A mammalian patched homolog is expressed in target tissues of sonic hedgehog and maps to a region associated with developmental abnormalities. $J$ Biol Chem. 1996;271:12125-12128.
30. Zurawel RH, Allen C, Chiappa S, et al. Analysis of Ptch/SMO/SHH pathway genes in medulloblastoma. Genes Chromosomes Cancer. 2000;27:44-51.

31. Bar EE, Chaudhry A, Farah MH, Eberhart CG. Hedgehog signaling promotes medulloblastoma survival via Bc/II. Am J Pathol. 2007;170: 347-355.

32. Berman DM, Karhadkar SS, Maitra A, et al. Widespread requirement for Hedgehog ligand stimulation in growth of digestive tract tumours. Nature. 2003;425:846-851.

33. Karhadkar SS, Bova GS, Abdallah N, et al. Hedgehog signalling in prostate regeneration, neoplasia and metastasis. Nature. 2004;431: 707-712.

34. Fan L, Pepicelli CV, Dibble CC, et al. Hedgehog signaling promotes prostate xenograft tumor growth. Endocrinology. 2004;145: 3961-3970.

35. Vorechovsky I, Benediktsson KP, Toftgard R. The patched/hedgehog/ smoothened signalling pathway in human breast cancer: no evidence for H133Y SHH, Ptch and SMO mutations. Eur J Cancer. 1999;35: 711-713.

36. Watkins DN, Berman DM, Burkholder SG, Wang B, Beachy PA, Baylin SB. Hedgehog signalling within airway epithelial progenitors and in small-cell lung cancer. Nature. 2003;422:313-317.

37. Hegde GV, Munger CM, Emanuel K, et al. Targeting of sonic hedgehog-GLI signaling: a potential strategy to improve therapy for mantle cell lymphoma. Mol Cancer Ther. 2008;7:1450-1460.

38. Hegde GV, Peterson KJ, Emanuel K, et al. Hedgehog-induced survival of B-cell chronic lymphocytic leukemia cells in a stromal cell microenvironment: a potential new therapeutic target. Mol Cancer Res. 2008;6:1928-1936.

39. Dierks C, Grbic J, Zirlik K, et al. Essential role of stromally induced hedgehog signaling in B-cell malignancies. Nat Med. 2007;13: 944-951.

40. Warzecha J, Bonke L, Koehl U, et al. The hedgehog inhibitor cyclopamine induces apoptosis in leukemic cells in vitro. Leuk Lymphoma. 2008;49:2383-2386.

41. Katoh Y, Katoh M. Hedgehog target genes: mechanisms of carcinogenesis induced by aberrant hedgehog signaling activation. Curr Mol Med. 2009;9:873-886.

42. Varnat F, Duquet A, Malerba M, et al. Human colon cancer epithelial cells harbour active HEDGEHOG-GLI signalling that is essential for tumour growth, recurrence, metastasis and stem cell survival and expansion. EMBO Mol Med. 2009;1:338-351.

43. Feldmann G, Dhara S, Fendrich V, et al. Blockade of hedgehog signaling inhibits pancreatic cancer invasion and metastases: a new paradigm for combination therapy in solid cancers. Cancer Res. 2007;67:2187-2196.

44. Rasheed ZA, Yang J, Wang Q, et al. Prognostic significance of tumorigenic cells with mesenchymal features in pancreatic adenocarcinoma. J Natl Cancer Inst. 2010;102:340-351.

45. Hui CC, Angers S. Gli proteins in development and disease. Annu Rev Cell Dev Biol. 2011;27:513-537.

46. Scales SJ, de Sauvage FJ. Mechanisms of Hedgehog pathway activation in cancer and implications for therapy. Trends Pharmacol Sci. 2009;30:303-312.

47. Sasaki H, Nishizaki Y, Hui C, Nakafuku M, Kondoh H. Regulation of Gli2 and Gli3 activities by an amino-terminal repression domain: implication of Gli2 and Gli3 as primary mediators of Shh signaling. Development. 1999;126:3915-3924.

48. Wicking $\mathrm{C}$, McGlinn $\mathrm{E}$. The role of hedgehog signalling in tumorigenesis. Cancer Lett. 2001;173:1-7.

49. Ruiz i Altaba A. Therapeutic inhibition of Hedgehog-GLI signaling in cancer: epithelial, stromal, or stem cell targets? Cancer Cell. 2008; 14:281-283.

50. Ruiz i Altaba A, Sanchez P, Dahmane N. Gli and hedgehog in cancer: tumours, embryos and stem cells. Nat Rev Cancer. 2002;2:361-372.

51. Yauch RL, Gould SE, Scales SJ, et al. A paracrine requirement for hedgehog signalling in cancer. Nature. 2008;455:406-410. 
52. Johnson RL, Rothman AL, Xie J, et al. Human homolog of patched, a candidate gene for the basal cell nevus syndrome. Science. 1996;272: 1668-1671.

53. Unden AB, Zaphiropoulos PG, Bruce K, Toftqard R, Stahle-Backdahl M. Human patched (Ptch) mRNA is overexpressed consistently in tumor cells of both familial and sporadic basal cell carcinoma. Cancer Res. 1997;57:2336-2340.

54. Dahmane N, Lee J, Robins P, Heller P, Ruiz i Altaba A. Activation of the transcription factor Glil and the Sonic hedgehog signalling pathway in skin tumours. Nature. 1997;389:876-881.

55. Aszterbaum M, Rothman A, Johnson RL, et al. Identification of mutations in the human PATCHED gene in sporadic basal cell carcinomas and in patients with the basal cell nevus syndrome. J Invest Dermatol. 1998;110:885-888.

56. Reifenberger J, Wolter M, Weber RG, et al. Missense mutations in $\mathrm{SMOH}$ in sporadic basal cell carcinomas of the skin and primitive neuroectodermal tumors of the central nervous system. Cancer Res. 1998;58:1798-1803.

57. Epstein EH. Basal cell carcinomas: attack of the hedgehog. Nat Rev Cancer. 2008;8:743-754.

58. Reifenberger J, Wolter M, Knobbe CB, et al. Somatic mutations in the Ptch, SMOH, SUFUH and TP53 genes in sporadic basal cell carcinomas. Br J Dermatol. 2005;152:43-51.

59. Robarge KD, Brunton SA, Castanedo GM, et al. GDC-0449-a potent inhibitor of the hedgehog pathway. Bioorg Med Chem Lett. 2009;19: 5576-5581.

60. Graham RA, Lum BL, Cheeti S, et al. Pharmacokinetics of hedgehog pathway inhibitor vismodegib (GDC-0449) in patients with locally advanced or metastatic solid tumors: the role of alpha-1-acid glycoprotein binding. Clin Cancer Res. 2011;17:2512-2520.

61. Giannetti AM, Wong H, Dijkgraaf GJ, et al. Identification, characterization, and implications of species-dependent plasma protein binding for the oral Hedgehog pathway inhibitor vismodegib (GDC0449). J Med Chem. 2011;54:2592-2601.

62. Graham RA, Lum BL, Morrison G, et al. A single dose mass balance study of the Hedgehog pathway inhibitor vismodegib (GDC-0449) in humans using accelerator mass spectrometry. Drug Metab Dispos. 2011;39:1460-1467.

63. Wong H, Chen JZ, Chou B, et al. Preclinical assessment of the absorption, distribution, metabolism and excretion of GDC-0449 (2-chloro-N-(4-chloro-3-(pyridin-2-yl)phenyl)-4-(methylsulfonyl) benzamide), an orally bioavailable systemic Hedgehog signalling pathway inhibitor. Xenobiotica. 2009;39:850-861.
64. Yue Q, Chen YH, Mulder T, et al. Absorption, distribution, metabolism, and excretion of $\left[{ }^{14} \mathrm{C}\right] \mathrm{GDC}-0449$ (vismodegib), an orally active hedgehog pathway inhibitor, in rats and dogs: a unique metabolic pathway via pyridine ring opening. Drug Metab Dispos. 2011;39: 952-965.

65. LoRusso PM, Jimeno A, Dy G, et al. Pharmacokinetic dose-scheduling study of hedgehog pathway inhibitor vismodegib (GDC-0449) in patients with locally advanced or metastatic solid tumors. Clin Cancer Res. 2011;17:5774-5782.

66. LoRusso PM, Rudin CM, Reddy JC, et al. Phase I trial of hedgehog pathway inhibitor vismodegib (GDC-0449) in patients with refractory, locally advanced or metastatic solid tumors. Clin Cancer Res. 2011;17: 2502-2511.

67. Keating GM. Vismodegib: in locally advanced or metastatic basal cell carcinoma. Drugs. 2012;72:1535-1541.

68. Aasi S, Silkiss R, Tang JY, et al. New onset of keratoacanthomas after vismodegib treatment for locally advanced Basal cell carcinomas: a report of 2 cases. JAMA Dermatol. 2013;149:242-243.

69. Axelson M, Liu K, Jiang X, et al. US Food and drug administration approval: vismodegib for recurrent, locally advanced, or metastatic Basal cell carcinoma. Clin Cancer Res. 2013;19:2289-2293.

70. Yauch RL, Dijkgraaf GJ, Alicke B, et al. Smoothened mutation confers resistance to a Hedgehog pathway inhibitor in medulloblastoma. Science. 2009;326:572-574.

71. Dijkgraaf GJ, Alicke B, Weinmann L, et al. Small molecule inhibition of GDC-0449 refractory smoothened mutants and downstream mechanisms of drug resistance. Cancer Res. 2011;71:435-444.

72. Therasse P, Arbuck SG, Eisenhauer EA, Wanders J, Kaplan RS, Rubinstein L et al. New guidelines to evaluate the response to treatment in solid tumors. European Organization for Research and Treatment of Cancer, National Cancer Institute of the United States, National Cancer Institute of Canada. J Natl Cancer Inst. 2000;92:205-16.

73. Sekulic A, Migden MR, Oro AE, et al. Efficacy and safety of vismodegib in advanced basal-cell carcinoma. NEngl J Med. 2012;366: 2171-2179.

74. Tang JY, Mackay-Wiggan JM, Aszterbaum M, et al. Inhibiting the hedgehog pathway in patients with the basal-cell nevus syndrome. N Engl J Med. 2012;366:2180-2188.

75. Chang AL, Oro AE. Initial assessment of tumor regrowth after vismodegib in advanced Basal cell carcinoma. Arch Dermatol. 2012;148: 1324-1325.
Cancer Management and Research

\section{Publish your work in this journal}

Cancer Management and Research is an international, peer-reviewed open access journal focusing on cancer research and the optimal use of preventative and integrated treatment interventions to achieve improved outcomes, enhanced survival and quality of life for the cancer patient The journal welcomes original research, clinical \& epidemiological

\section{Dovepress}

studies, reviews \& evaluations, guidelines, expert opinion \& commentary, case reports \& extended reports. The manuscript management system is completely online and includes a very quick and fair peerreview system, which is all easy to use. Visit http://www.dovepress.com/ testimonials.php to read real quotes from published authors. 